\title{
On-Street Parking Prohibition and Travel Behaviour of Motorists in Aba, Nigeria
}

\author{
Ogbonna Chukwuemeka Godswill
}

Department of Urban and Regional Planning, Abia State Polytechnic P.M.B 7166 Aba, Abia State, Nigeria Tel: 234-703-3807557.

\begin{abstract}
The prevalence of on-street parking in the city of Aba has continued to generate much concern to all road users and the government in Nigeria as it hinders traffic flow and increases traffic accidents. Consequently, the government initiated the policy of on-street parking prohibition at the downtown area of Aba, leading to increased travel difficulty for motorists. This study examined the policy of on-street parking prohibition and the resultant travel behaviour of motorists. The study adopted survey design whereby primary data were collected with the aid of structured questionnaire, measurement, and observation. The sample size of 400 respondents was determined from the study population of 420,665 motorists using the Standard Traffic Count (STC) approach. Cluster, purposive and simple random sampling techniques were used to proportionately select the roads and respondents used in the study. Analysis of variance (ANOVA) and Chisquare were used for data analysis. The study revealed among other thing that: there were significant differences in the geometric characteristics of roads where on-street parking was prohibited and where on-street parking was not prohibited. On-street parking prohibition was found to have impacted the travel behaviour of motorists as follows: (i) motorists travel less with single occupancy vehicles (SOVs) but more with KEKE (tricycle) during the working hours; (ii) there is reduction in the frequency of trips by motorists to the city centre whereas they divert to the outlying areas; and (iii) there is increased city bound (nonwork) trips during early morning and late evening hours. It was recommended among others that government should embark on the construction of modern off-street parking facilities at designated locations within the city of Aba. Government should also recover sidewalks and road setbacks which have been totally invaded by commercial activities in Aba, and develop paid curb-parking there as alternative to on-street parking.
\end{abstract}

Keywords- On-street, Parking, Travel behaviour, Motorists, Aba, Nigeria.

\section{INTRODUCTION}

Car parking especially in the city centre plays a key role in mobility, access and economic development of what appears to be an ever more car-dependent society (Rye, 2005). The city centre car parking market is a sector of the economy that has increased in importance as the market for cars has grown. Cars have become a fundamental element of journey and, in consequence, parking has as well. The car-parking sector has always been of great importance in terms of urban mobility, since it is a fundamental element in achieving a high level of accessibility in city centres. Many businesses and municipalities see an adequate supply of parking, especially for visitors, as crucial for their competitive growth. Yet, at the same time parking is, and will remain for most cities, one of the most powerful means of traffic restraint available (Andrew and Peter, 2006). The economics of car parking is also important because it is for both public and private organisations, a key source of revenue. All over the world, the demand for private-car access to cities and towns has continued to grow because of the presence of many attractions, such as public and private services, shopping and tourist centres. Since each trip has destination, therefore there is a corresponding increase in demand for parking spaces. But in most cases (especially in developing countries) developers hardly make provision for adequate off-street parking. This is because, just as Shoup (2005) observed, if everyone can easily get free parking on the street, developers have little incentive to build off-street parking and little ability to charge for the parking spaces they build. As a result, city travellers quite often do not find parking space within the property, and are forced to park on the street or engage in spill over parking on adjacent properties. The act of parking vehicles on one or both sides of the road is what is referred to as On-Street Parking.

For many years, the role of parking policy in most developed countries was to accommodate the automobile commuter by providing convenient spaces to park. As cities grew and became more complex, decision makers favoured removal of on-street parking from major arterials. They 
argued that this action might increase road capacity and improve traffic flow and safety (Kennedy, 1994). On the other hand, arguments for allowing on-street parking have traditionally based on the potential benefits to the local merchants. Accessibility and parking convenience are among major factors that affect shoppers' destination choices (Andrew and Peter, 2006). Prior to the first offstreet parking facilities, on-street parking had been present and naturally supplied as part of road construction, but nowhere was it regulated. With the advent of off-street parking, many larger cities like Chicago, Detroit, and Philadelphia began eliminating on-street parking to improve traffic flow (WashDOT, 1999). Others, however, took a different approach: in 1935, Oklahoma was the first city to regulate on-street parking using meters. In recent years, several communities around the world have used on-street parking prohibition and management strategies as means of achieving a wide variety of community objectives, ranging from reduction in auto trips, increased transit ridership, reduction in congestion, to improved air quality (Meyer et. al., 1983). Kennedy (1994) in a study of the city of Soul found out that prohibiting or decreasing long-term on-street parking attracted additional short-term parkers, promoted transit patronage among long-term parkers, improved highway level of service, and promoted economic growth through increased retail sales.

In several other cities of the developed world there is considerable technology available for managing on-street parking, including mobile phones, ticket machines, camera enforcement, information technology for record keeping systems, et cetera, but in most cities in low income countries, manual collection systems are used (Rye, 2011). Martin (2008) has reported on the Westminster city parking system in London where a limited number of parking pricing systems have been implemented. In February 2009, Chicago city officials leased the city's metered parking spaces to private investors for a term of 75 years to attract capital to upgrade the existing parking system. In San Francisco, local agencies built a system using real-time parking data to manage congested streets and relieve a parking shortage (Battelle et. al., 2011). An analysis of the Columbia District's parking management program indicated that implementation of the on-street parking enforcement program has resulted in reduced parking violation, increased on-street parking availability for short-term parkers, and significantly increased revenues from meter operations and fines (Ellis, 1987). According to Rye (2011), after an increase in on-street parking fees in Shenzhen, China, a remarkable $30 \%$ drop in demand was recorded. The benefits associated with this were short lived as the policy was reversed in 2007 and the demand soared so that the central business district was gridlocked.

In African perspective the absence of city-wide parking policies in the past has given rise to varied measures which are haphazardly applied. In some instances, placement of parking does not required action, only removal of parking does. This is because, except for roadways where parking is prohibited by statute (e.g., freeways and expressways), parking is assumed to be allowed until a specific order prohibiting it at a particular location is issued. Recently African cities appear to be waking up to the need for parking regulations. The city authorities in Cape Town have adopted the following mechanisms to address a range of parking matters: Cape Town Zoning Scheme (CTZS), Park $\&$ Ride facilities, On-street Park and pay, Parking By-law, and the Interim Policy Framework and Strategy for the Pricing of Parking (Kok, 2013). The city of Adum in Ghana established paid parking scheme in June 2006 with the objective to control on-street parking, reduce congestion through reduction of parking duration and increase in parking turnover (Charles, et. al., 2014). In Egypt, the government introduced a policy in 2010 aimed at promoting modal shift from private cars to sustainable integrated public transport for Greater Cairo and its satellite cities by restricting on-street parking and introducing privately operated high quality off -street parking facilities (Mohamed, 2012). The Kampala City Council awarded a contract for the management of paid on-street parking in the central business district to the private sector in 1997. This was in response to the ever increasing congestion in the central business district. The price of parking was UGX 400 (US\$ 0.17) per hour. A new ticket was purchased every hour up to 3 hours after which parking is illegal (Rye, 2011). Enforcement tactics, such as aggressive ticketing, towing, and booting illegally on-street parked vehicles have been used in many cities around Africa as in other parts of the world (Rye, 2011). They are not new, yet the use and integration of such tactics to meet broader transportation, economic, environmental and related objectives has received little attention, at least in the literature. In most communities, the police department is responsible for parking enforcement. Police priorities and sparse resources frequently become issues of prime consideration; in times of budget restrictions, parking enforcement is often one of the first targets for cuts (Kennedy, 1994). Consequently, there is an increasing trend toward using civilian personnel to enforce parking regulations. Parking characteristics of most other cities in Africa are similar, with ample supply of 
free on-street parking spaces which are often utilized to full capacity, resulting most times to increase in traffic congestion (Olorunfemi, et. al., 2014).

On-street parking constitutes one major problem that makes traffic situation chaotic in Nigerian cities (Osoba, 2012). Many Nigerian cities have narrow roads which lack pedestrian lanes. There are cases of double parking along these narrow roads thereby exacerbating traffic congestion. Property development in the cities is characterized by fenced compounds, and this creates exclusive interior parking spaces for residents of the compound while restricting off-street parking for visitors (Asiyanbola and Akinpelu, 2012). Majority of the cities are experiencing rapid rate of urbanization and the spatial expansion of the urban centres. This growth trend comes along with both increasing car ownership, and travel demand for shopping, leisure, education, work, and other urban activities (Osoba, 2012). As a result, most of the cities experience chaotic parking condition as well as intense traffic congestion, with cities like Lagos, Port-Harcourt, Kano, Abuja, Owerri, Aba, Uyo, Calabar, Onitsha, Kaduna, and Minna being worse off. The parking situation in the central area of Aba has continued to generate much concern to both commuters and operators of business outfits in the area. Venues of activities such as offices, markets, shops, sports, churches and similar places often generate enormous parking demands, and the difficulty of parking vehicles at desired destinations particularly when located within the down town area of the city constitutes a major problem, becoming phenomenal in the face of increasing number of private car ownership. Huge packing demand coupled with ineffective parking management impact negatively on urban road space. The scramble for on-street parking spaces by motorists has posed serious challenge as it is arguably affecting traffic condition, volume of trips to the city, and general activities in the city centre. On-street parking is such a serious problem in the area that it erodes the available street space to the extent of causing inconvenience for pedestrians, hindering traffic flow, increasing traffic accidents, impeding access to the side-walks and degrading its function to prevent disasters. It is common experience for the shopping corridors downtown to be blocked by heavy duty trucks which are either loading or offloading goods. Shoppers are often seen driving around in search of on-street space to park, thereby exacerbating traffic congestion. Government regulation has recently prohibited on-street parking at some major roads in the downtown area of Aba. The neighbourhoods mostly affected are: Azikiwe road, Asa road, Tenant road, Ehi road, Hospital road, Kent road, Park road, and Jubilee road. Others are East road, School road, Cameroon road, Pound road, St-Michael's road, Constitution crescent, and Judges road. Consequently there has been increasing difficulty for motorists to secure parking location, and it is believed that this has affected their travel behaviour.

In Nigeria, government technical and regulatory innovations for traffic have mainly focused on mass transit issues and road rehabilitation. Previous researchers on the issue of onstreet parking in Nigeria such as Olorunfemi et. al. (2014); Ahmed (2014); Osoba (2012); Asiyanbola and Akinpelu (2012); Aderamo et. al. (2011); and Obot et. al. (2009) studied the relationship between parking and traffic congestion, but did not address the emerging trend in parking policies and its effects on mobility at city centres. There is paucity of knowledge of the car parking market and its dynamics as there is lack of comprehensive parking policy for most cities. Parking regulations are often arbitrarily assigned just as the case in the concession of onstreet parking pricing and ticketing to private firms in Abuja in 2014, and the prohibition of on-street parking in the core area of Aba in 2012. With the city of Aba as the focus of enquiry the study examined the effects of on-street parking prohibition on travel behaviour of motorists.

\section{METHODOLOGY}

The study is focused on the city of Aba in south-eastern Nigeria (see figure 1 for map of Abia State and Aba). Aba is located approximately between latitudes $5^{\circ} 05^{\prime} \mathrm{N}$ to $5^{\circ} 08^{\prime}$ north, and longitude $7^{\circ} 20^{\prime} \mathrm{E}$ to $7^{\circ} 28^{\prime}$ east, and has sprawled to an approximate area of $26.7 \mathrm{~km} 2$. The city has witnessed a high rate of urbanization which has turned it into different blocks of commercial layouts with casual and haphazard mixture of buildings, ranging from make-shift stores and shops to warehouses under large building with several floors. Within the suburb, prime agricultural lands give way to scattered ribbons of low income homes and businesses, stretching finger-like along rural road ways and streets. Urban Infrastructure is of poor quality: most of the roads lack pedestrian provisions; street lighting; parking corridors or curb parking; and bus stops. Vehicles are frequently packed at the road setbacks, especially on places that should serve for utility and sanitary purposes. Aba being a commercial town has many institutions; banks, company offices and business outlets, public and private schools and hospitals dot the entire landscape. Because of this, Aba is an important regional economic hub for Nigeria, which impacts the volume of trip generation and traffic volume in the city. 
The study adopted survey design. Both primary and secondary sources of data were used in the study. Primary data were collected with the aid of structured questionnaire, measurement, and observation. Secondary data were obtained from the Abia State Ministry of Transport handbooks. The study population consists of motorists drivers of motor vehicles (excluding motorcycles) comprised of: commercial motorists, mainly Para-transit mode operators (mini-bus, taxi, and tricycle also known as $K E K E$ in local parlance); and drivers of private cars. Some categories of motorists excluded from the study include mass transit bus drivers and lorry drivers. They were excluded because, pilot studies carried out earlier showed that these classes of motorists do not have significant contribution to on-street parking in the area as they were found to park vehicles in their off-street terminals. The population of motorists in Aba is 420,665, comprising 116,816 private motorists and 303,849 commercial motorists, and this represents average number of motorists that operate in the city daily. This data was collected from the licensing office of the Inland Revenue (Board of Internal Revenue) and the ministry of transport office, and validated through an independent traffic count by the author. The sample size of 400 respondents was determined from the study population using the Standard Traffic Count
(STC) sample size determination formula. The survey recorded $92 \%$ success as 364 properly filled copies of questionnaires were returned and used for analysis. Cluster, purposive and simple random sampling techniques were used to proportionately select the roads and respondents used in the study. Cluster sampling technique was applied to divide the study area into two zones based on the areas where on-street parking was prohibited and the areas where on-street parking was permitted; and to divide each zone into four quadrants for purposes of fair representation. Purposive sampling techniques was used to select motorists at their loading bays and on-street parking positions along the roads, due to the reason that they were always on the move and were more disposed to rejecting interview requests. Then questionnaires were sampled proportionately on all the roads, at the ratio of 1:3 between private motorists and commercial motorists. The geometric variables of the roads (road carriageway width, shoulder width, parking capacity) were measured with Measuring Wheels. Reliability test of the instrument was determined using Cronbach's alpha which yielded a correlation co-efficient of 0.80. Analysis of variance and Chi-square were used to analyze the data and to test the research hypotheses at 0.05 significance level, making use of SPSS for windows version 17.

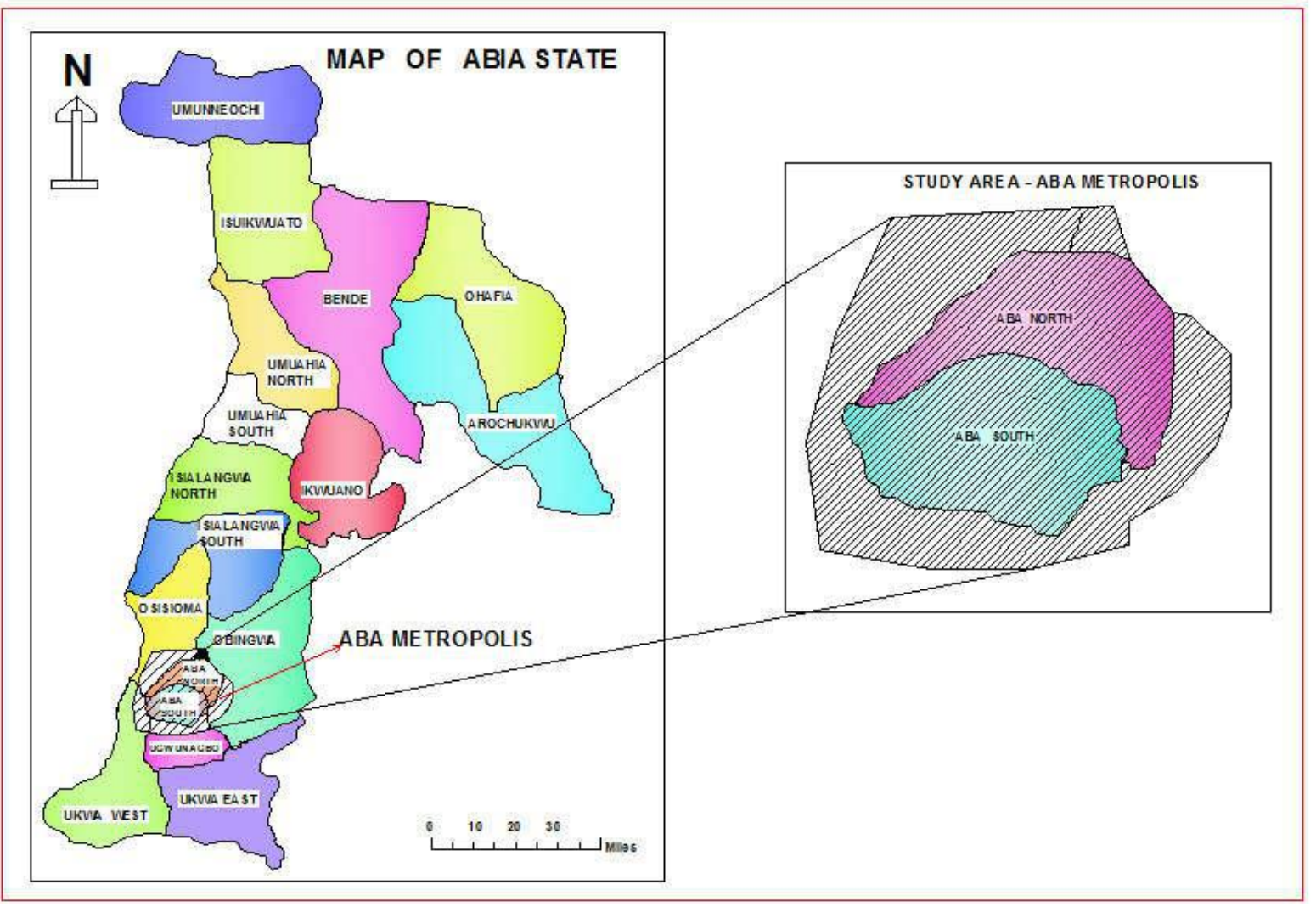

Fig.1: map of Abia State showing the metropolitan area of Aba 


\section{RESULTS AND DISCUSSION}

\subsection{Choice of Travel Mode}

Choice of travel mode in the study area is affected by period of enforcement of on-street parking prohibition. Therefore choice of travel mode for motorists in the study area was derived for three different periods of the day corresponding with strength of enforcement by traffic officers. These periods are: early morning hours (5.00am $-8.00 \mathrm{am})$; Day time or working hours $(8.00 \mathrm{am}-5.00 \mathrm{pm})$; and Late Evening hours $(5.00 \mathrm{pm}-10.00 \mathrm{pm})$. Three different surveys were carried out to determine the choice of travel mode for the different periods of the day.
3.1.1 Choice of Travel Mode for Early Morning Hours This period correspond with the time between when motorist begin to leave their houses in the morning (around 5.00am) and the time of commencement of daily working hours $(8.00 \mathrm{am})$. Figure 2 shows that 43 persons $(11.8 \%$ of respondents) drive their cars to the downtown (CBD) during early morning hours, 41 persons $(11.2 \%)$ enter mini-buses during same time, 7 persons (1.9\%) enter taxi cabs, while majority of the people 272 persons or $(74.5 \%)$ go to town with $K E K E$ (tricycle).

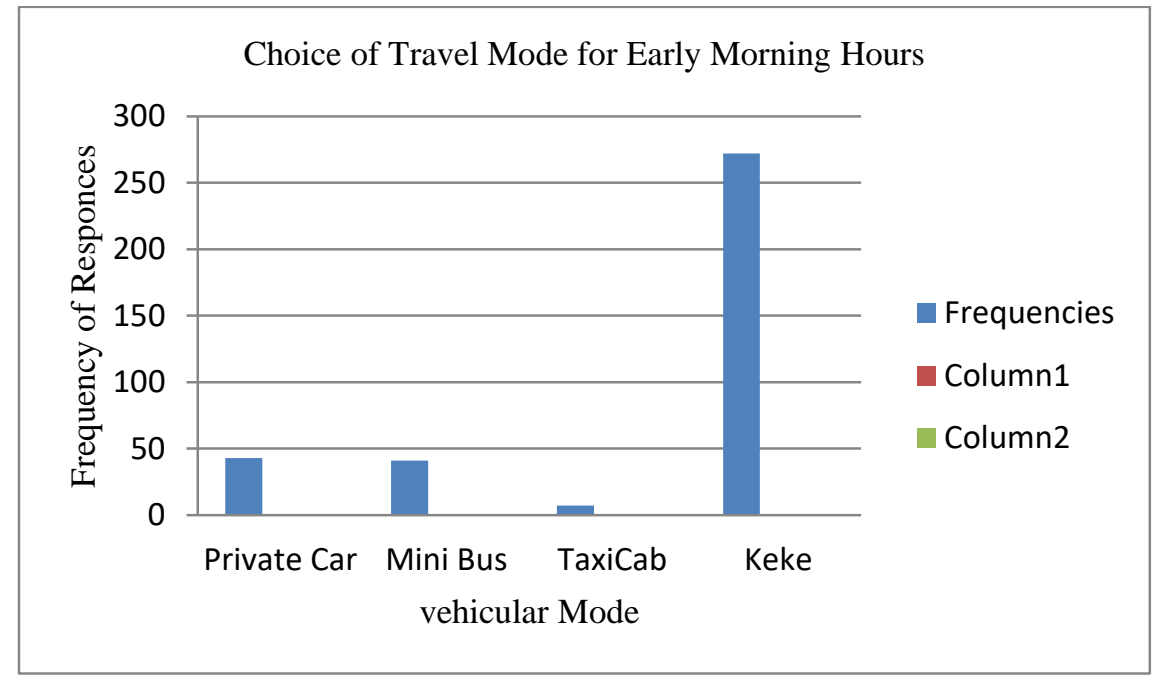

Fig.2: Choice of travel mode for early morning hours

\subsubsection{Choice of Travel Mode for Day Time (8am - $5.00 \mathrm{pm})$}

This period is the working hours of the civil service and therefore account for period of maximum enforcement because the enforcement officers are on patrol. Figure 3 indicate that motorists overwhelmingly choose to travel downtown with KEKE during working hours (317 respondents - 87\%) while 30 persons (8\%) travel with Minibus. 17 persons (5\% of respondents) travel with their private cars while no person travel with taxi cab.

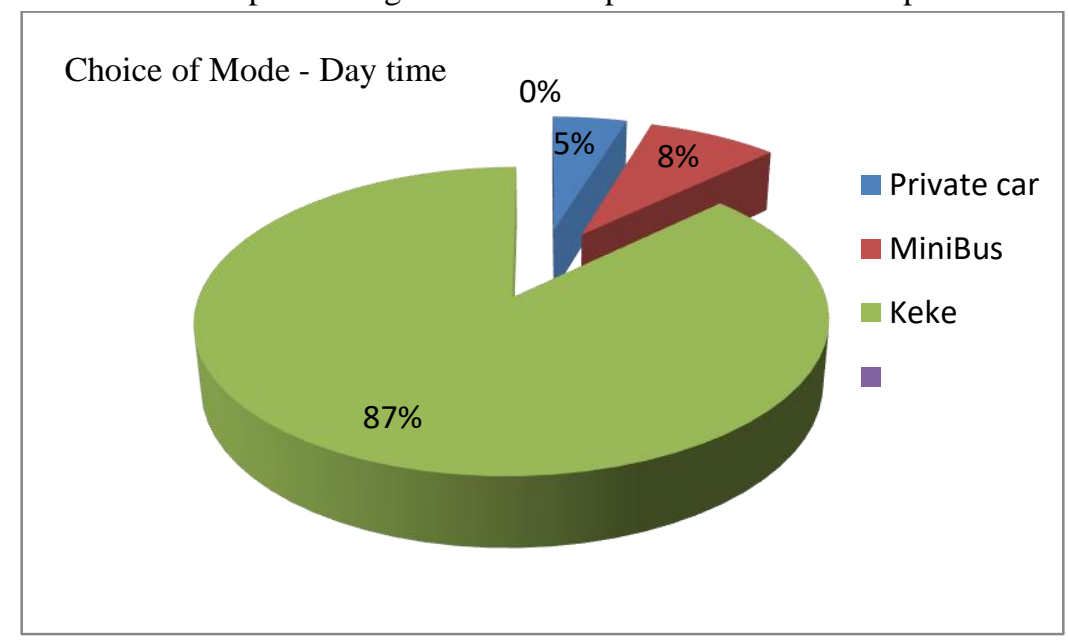

Fig.3: Choice of transport mode by day time 
3.1.3 Choice of Travel Mode for Late Evening (5.pm -10.pm)

By this period the taskforce for on-street parking prohibition must have closed work. Therefore their absence from the streets influences choice of mode of vehicular travel by motorists as shown on figure 4. This survey recorded higher choice of travel mode for private cars in the evening hours with 113 persons $(31 \%)$, choice of $K E K E$ mode decreased to 187 (52\%), mini-bus increased to 53 $(15 \%)$, while taxi is $7(2 \%)$.

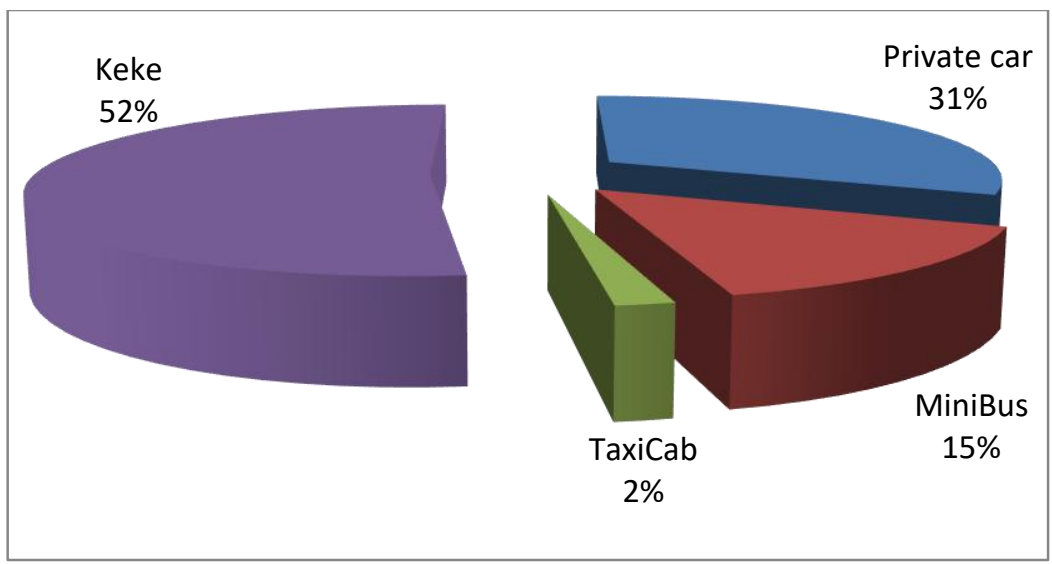

Fig.4: Choice of travel mode for during late evening

\subsection{Volume of Trips to the downtown (CBD)}

Like Choice of travel mode, Volume of trips to the central area of Aba is affected by period of enforcement of onstreet parking prohibition. Therefore volume of trips was derived for the three primary periods identified in this study. The first of these is the early morning hours (5.00am $-8.00 \mathrm{am})$.

\subsubsection{Volume of trips for early morning hours}

Table1 shows that over $62 \%$ of respondents (225 persons) make an average of 1 to 2 trips per week (for the private motorist), and 1to 2 trips per day (for commercial vehicle operators) to the CBD. Also over 36\% (131persons) make between 3 - 4 trips per week (or per day) as applicable. Other frequencies here were insignificant.

Table.1: Volume of trips to the CBD during Early Morning hours

\begin{tabular}{|l|llll|}
\hline Trip Volume & Frequency & $\%$ & Valid \% & Cumulative \% \\
\hline $1-2$ & 225 & 61.6 & 62.5 & 62.5 \\
$3-4$ & 131 & 35.9 & 36.4 & 98.9 \\
$5-6$ & 1 & .3 & .3 & 99.2 \\
above 6 & 3 & .8 & .8 & 100.0 \\
\hline Total & 360 & 98.6 & 100.0 & \\
\hline
\end{tabular}

\subsubsection{Volume of trips to the CBD during Daytime (8am} $-5 \mathrm{pm})$

This period is the working hours; ordinarily every worker would travel at this time. But the survey did not measure work trips. Trips measured are non-work trips like trips for shopping, leisure, and errand. The results (table 2) show that 320 persons ( $88.4 \%$ of respondents) made 1 to 2 trips to the CBD per week, and per day for private motorists and commercial motorists respectively. On the other hand, 42 persons (11.6\%) made 3 to 4 trips per week, or per day as applicable. 
Table.2: Volume of trips to the CBD during Daytime

\begin{tabular}{|l|llll|}
\hline Trip Volume & Frequency & Percent & Valid \% & Cumulative \\
\hline & & & & $\%$ \\
$1-2$ & 320 & 87.7 & 88.4 & 88.4 \\
$3-4$ & 42 & 11.5 & 11.6 & 100.0 \\
\hline Total & 362 & 99.2 & 100.0 & \\
\hline
\end{tabular}

3.2.3 Volume of Trips to the CBD during Evening (5pm - 10pm)

This survey shows trip volume of motorists after working hours. The survey (see table 3) indicates that 110 persons (30.6\% of respondents) made 1 to 2 trips to the CBD, 216 persons $(60 \%)$ made between 3 to 4 trips to the CBD, 29 persons $(8.1 \%)$ made 5 to 6 trips, while 5 persons reported making above 6 trips per week for private motorists, and per day for commercial motorists respectively.

Table.3: Volume of Trips to the CBD during Evening

\begin{tabular}{|l|llll|}
\hline Trip Volume & Frequency & $\%$ & Valid \% & Cumulative \% \\
\hline & & & & \\
$1-2$ & 110 & 30.1 & 30.6 & 30.6 \\
$3-4$ & 216 & 59.2 & 60.0 & 90.6 \\
$5-6$ & 29 & 7.9 & 8.1 & 98.6 \\
above 6 & 5 & 1.4 & 1.4 & 100.0 \\
\hline Total & 360 & 98.6 & 100.0 & \\
\hline
\end{tabular}

Source: Researcher's survey, (2015).

\subsection{Trip Destination}

It was speculated that the activities of the taskforce on onstreet parking prohibition affect the choice of travel destination by motorists, with choice of destination varying between the downtown area where on-street parking is prohibited, and the outlying areas where it is presently not prohibited. Therefore this survey investigated the veracity of this assertion, considering the three periods of the day that correspond to the strengths of on-street enforcement identified in the study area.

\subsubsection{Trip destinations early Morning hours}

Figure 5 shows that 242 respondents (66.9\% of motorists) travel to downtown (CBD) during early morning hours for non-work trips, whereas the rest 120 respondents (33\%) travel to the outlying areas for non-work trips.

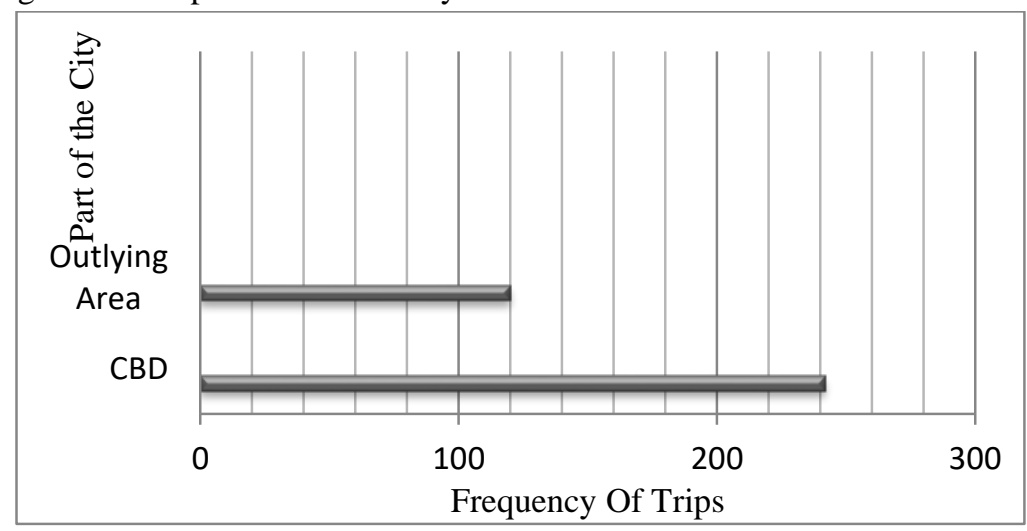

Fig.5: Trip destinations early morning hours

\subsubsection{Trip Destination during Day Time}

The frequency of trips by motorists during the day time (see table 4) showed that 146 motorists $(40 \%)$ travelled to the
CBD, but 218 (60\%) preferred to travel to the outlying areas for business, leisure, errand, and other non -work activities. 
3.3.3 Trip Destination during Late Evening Period

This survey captured trip destination of motorists after the working hours, for non-work trips (Table 5). It showed an increase in the frequency of trips whose destination were at the CBD, with 240 out of 365 respondents $(65.9 \%)$ visiting the $\mathrm{CBD}$, and $123(33.8 \%)$ of respondents visiting the outlying areas. This reversal of trips towards the city centre around evening time is attributed to the fact that the task force for on-street parking enforcement must have closed work at this time, and motorist were at less risk of being impounded for contravening the parking regulation hence they choose to drive downtown.

Table.4: Trip Destination during Day Time

\begin{tabular}{|c|cccc|}
\hline & Frequency & $\%$ & Valid \% & Cumulative \% \\
\hline CBD & 146 & 40.0 & 40.1 & 40.1 \\
Out lying area & 218 & 59.7 & 59.9 & 100.0 \\
\hline Total & 364 & 99.7 & 100.0 & \\
\hline
\end{tabular}

Source: Field survey, 2016

Table.5: Trip destinations during late evening period

\begin{tabular}{|l|llll|}
\hline & Frequency & Percent & Valid \% & Cumulative \% \\
\hline CBD & 240 & 65.8 & 65.9 & 65.9 \\
Out lying areas & 123 & 33.7 & 33.8 & 99.7 \\
11 & 1 & .3 & .3 & 100.0 \\
\hline Total & 364 & 99.7 & 100.0 & \\
\hline
\end{tabular}

Source: Field survey, 2016

\subsection{Application of Traffic Management Laws in Aba}

A survey was conducted to determine methods by which on-street parking prohibition is enforced in the area. Respondents identified the following measures as being applied by the taskforce on parking prohibition for enforcement (see table 6).

a) 281 persons $(77.2 \%)$ of respondents reported having received all the outlined measures at one time or another, which include vehicle impoundment, payment of fines, beating-up/harassment, detention in police cell, and prosecution in court.

b) 20 persons $(5.5 \%)$ reported having been prosecuted only c) 15 motorists $(4.1 \%)$ indicated vehicle impoundment and payment of fines

d) 11 persons $(3.0 \%)$ said they have paid only fines

e) 10 motorists $(2.7 \%)$ said they have experienced vehicle impoundment, payment of fines, beating/harassment, and detention in police cell

f) 10 respondents $(2.7 \%)$ reported having been detained in police cell only

g) 9 respondents $(2.5 \%)$ indicated having been beaten up only

h) 6 persons $(1.6 \%)$ indicated having experienced impoundment of vehicle, payment of fines, beating and harassment.

Table 6: Enforcement of on-street parking prohibition

\begin{tabular}{|l|l|l|l|l|}
\hline Enforcement Strategy & Freq. & Percent & Valid \% & Cumulative \% \\
\hline Impound vehicle & & & & \\
Fines & 2 & .5 & .5 & .5 \\
Beating/harassment & 11 & 3.0 & 3.0 & 3.6 \\
Detention & 9 & 2.5 & 2.5 & 6.0 \\
Prosecution & 10 & 2.7 & 2.7 & 8.8 \\
Impound vehicle \& Fines & 20 & 5.5 & 5.5 & 14.3 \\
Impound vehicle \& Fines \& beating/harassment & 15 & 4.1 & 4.1 & 18.4 \\
Impound vehicle \& Fines \& beating/harassment \& & 10 & 2.7 & 2.7 & 20.1 \\
\end{tabular}




\begin{tabular}{|l|l|l|l|l|}
\hline Enforcement Strategy & Freq. & Percent & Valid \% & Cumulative \% \\
\hline $\begin{array}{l}\text { detention } \\
\text { All of the above }\end{array}$ & 281 & 77.0 & 77.2 & 100.0 \\
\hline Total & 364 & 99.7 & 100.0 & \\
\hline
\end{tabular}

Source: Researcher's survey, (2016).

\subsection{Hypothesis Testing}

The study examined three different hypotheses which were targeted at establishing the effects which on-street parking prohibition has on travel behaviour of motorists.

3.5.1 Hypothesis one. Ho: There is no significant difference in the geometric characteristics of the roads where on-street parking was prohibited and roads where on-street parking was not prohibited in the study area.

The result showed that there was a significant difference in the geometric characteristics of the roads where on-street parking was prohibited against roads where on-street parking was not prohibited in the study area $(\mathrm{F}=18.8, P=$ $0.001 ; P<0.05$ significant level). The null hypothesis was rejected (see Appendix A-1 for details).

The carriageway widths of roads downtown were narrower than those in the outlying areas where on-street parking prohibition is not operational as shown in appendix A-2. This as well means that a recommendation for width expansion of some of the downtown roads in Aba is reasonable. Secondly, the on-street parking capacity on roads where policy on prohibition is operational downtown is relatively small. This has some traffic implications. Thus, the need to actually increase parking capacity on roads where prohibition policy is operational cannot be overemphasised. In addition, road shoulder widths for the downtown roads were narrower than those at the outlying areas. On-street parking ordinarily should be done on the road shoulder not on major road lane. Because road shoulder widths of the downtown roads were narrower, onstreet parking significantly affects the carriageway leading to congestion. This necessitated the on-street parking prohibition in the first instance. It therefore means that expansion of the road shoulder widths of the CBD roads would accommodate marginal on-street parking without creating the usual traffic challenges.

3.5.2 Hypothesis Two: Three sub-hypotheses were formulated to test effects of parking prohibition as follows:

Ho: The policy of on-street parking prohibition does not significantly affect the travel behaviour of motorists in Aba, (travel behaviour as measured by choice of transport mode, frequency of trip, and choice of travel destination).

i. Effects of on-street parking prohibition on choice of travel mode. The analysis was conducted using SPSS for Windows; program output can be seen at Appendix - B1. The result of the $3 \times 4$ Chi-square showed the following:

1. $\mathrm{X}^{2}$ value for Private car mode $=133.225$, with $(P)$ value of 0.000 , which is statistically significant at 0.05 significant level

2. $\mathrm{X}^{2}$ value for Mini-Bus mode $=40.518$, with $(P)$ value of 0.000 , which is statistically significant at 0.05 significant level

3. $\mathrm{X}^{2}$ value for Taxi cab mode $=7.00$, with $(P)$ value of 0.321 , is not statistically significant at 0.05 significant level

4. $\mathrm{X}^{2}$ value for $K E K E$ mode $=88.399$, with $(P)$ value of 0.000 , which is statistically significant at 0.05 significant level

ii. Effects of on-street parking prohibition on volume of trip. The SPSS output data for this analysis can be seen in Appendix - B2. The result is summarized as follows:

1. $\mathrm{X}^{2}$ value for Volume of trip between 1 and $2=54.519$, with $(P)$ value of 0.000 , which is statistically significant at 0.05 significant level

2. $\mathrm{X}^{2}$ value for Volume of trip between 3 and $4=66.739$, with $(P)$ value of 0.000 , which is statistically significant at 0.05 significant level

3. For Volume of trip between 5 and 6 No statistics were computed because Volume of trip during Evening hours and Volume of trips during day time were constants.

4. Also, for Volume of trips above 6, No statistics were computed because Volume of trip during Evening hours and Volume of trips during day time were constants.

iii. Effects of on-street parking prohibition on Choice of travel destination. The SPSS output data for this analysis has been attached as Appendix - B3. The result is summarized as follows: 
1. $\mathrm{X}^{2}$ value for Travel destination downtown $(\mathrm{CBD})=$ 61.533 , with $(P)$ value of 0.000 , which is statistically significant at 0.05 significant level

2. $\mathrm{X}^{2}$ value for Travel Destination Outlying Areas = 88.621 , with $(P)$ value of 0.000 , which is statistically significant at 0.05 significant level.

Inference: Results from variables in $\mathrm{i}, \mathrm{ii}$, and iii above are significant, therefore we reject the null hypothesis in all and accept the alternative hypothesis which states that the policy of on-street parking prohibition significantly affect the travel behaviour of motorists in Aba, (travel behaviour as measured by choice of transport mode, frequency of trip, and choice of travel destination).

3.5.3 Hypothesis Three. Ho: There is no significant difference between the travel behaviour of motorists (as measured by choice of mode and frequency of trips) when their destination is downtown (where on-street parking is prohibited), and when their destination is outlying areas (where on-street parking is permitted).

1. Result for Travel Behaviour as measured by Choice of Mode showed $X^{2}$ value of 317.425 , with $(P)$ value of 0.000 , which is statistically significant at 0.05 significant levels, (see appendix B4)

2. For Travel behaviour as measured by frequency of Trips, the result showed $\mathrm{X}^{2}$ value of 220.975 , with $(P)$ value of 0.000 , and this is equally statistically significant at 0.05 significant levels (see appendixes B5).

Inference: Results from both variables are significant, therefore the null hypothesis was rejected, and the alternative hypothesis: there is significant difference between the travel behaviour of motorists (as measured by choice of mode and frequency of trips) when their destination is downtown (where on-street parking is prohibited), and when their destination is outlying areas (where on-street parking is permitted) is accepted.

\subsection{Other Effects of On-street Parking Prohibition}

The study revealed other positive and negative effects of on-street parking prohibition in the study area. The positive effects include:

i. Reduction in volume of trips to the city centre during working hours, which directly improves traffic flow on the affected roads. ii. Reduction in the level of traffic congestion at the city centre during pick hours $(7.00 \mathrm{am}-10 \mathrm{am}$; and $4.00 \mathrm{pm}$ to $7.00 \mathrm{pm})$.

iii. Reduction in rate of accidents due to indiscriminate onstreet parking

iv. Better safety to pedestrians who simply use the roadsides in the absence of pedestrian walk ways.

v. Better accessibility to emergency vehicles like ambulance and fire engines during emergencies

vi. Enforcement of on-street prohibition has encouraged private sector investment in off-street parking on commercial basis. Presently pay-as-you-go off street Motor-Parks are fast springing up in the city of Aba.

vii. On-street parking prohibition and enforcement is also a source of internally generated revenue for the State and Local Governments. Presently the traffic enforcement agency is a major revenue generating agency of government through fines, and charges.

There are however negative effects of the on-street parking prohibition policy as reported by respondents during the surveys. These include:

i. Reduction in volume of business at the city centre. The down town shopping centres reported reduced patronage mostly at major activity centres since the prohibition of on-street parking.

ii. There have been various reported cases of fighting and community uproar between the traffic officers and motorists over contravention of on-street parking regulations.

iii. The use of KEKE (tricycle) for commercial transport has been heightened by the prohibition of on-street parking. This is because parking problem affects buses, taxicabs and private vehicles (that occupy larger spaces, and need to park at a location either for loading and offloading or for the occupants to run their errands) more than the KEKE. Most times KEKE drivers are always on the move and may not need much space to park. The dominance of KEKE in urban transport system of Aba has lots of attendant difficulties: in the first place there are too many of the vehicles on any smaller section of the road space, also leading to congestion. Moreover the comparative speed of KEKE is very slow, and the passenger capacity also small. All these make it a major contributor to traffic congestion, though this needs to be properly investigated for conclusive evidence. 


\section{CONCLUSION AND RECOMMENDATIONS}

This study investigated the effects of on-street parking prohibition on travel behaviour of motorists in the city of Aba. The study revealed that on-street parking prohibition has affected the choice of travel mode and the frequency of trips by motorists when travelling to the downtown area of the city. Besides, it has also affected motorists' choice of destination (whether to visit downtown or the outlying areas) when they embark on shopping trips, leisure or errand. The study observed that while prohibition of onstreet parking has brought some relief to the city centre in terms of reduced congestion and accidents, it is gradually shifting travel and shopping pattern in favour of the outskirts, and this may be detrimental to the economic viability of the down town areas at the long run. These results also indicate that people who travel to the downtown area of Aba for activities other than work drive less and ride $K E K E$ more, than when they travel to other parts of the city. The implication of this is the proliferation of $K E K E$ on urban roads in Aba, as well as gradual reduction in downtown activities. This result suggests that parking policies that absolutely limit the amount of parking available to motorist without alternatives is counter productive to the goals of parking and traffic management. Therefore there is need for a review of traffic management policies in Aba especially as it applies to on-street parking. The author has therefore proposed the following recommendations.

1. The government should embark on the construction of modern off-street parking facilities at designated locations within the city of Aba. Presently only one offstreet park dedicated to the public exists in the town, and this is grossly inadequate.

2. The town planning authorities should cause the government to promulgate parking minimums which must be enforced as part of commercial and residential property development in urban areas. This will guarantee adequate supply of off-street parks especially at the downtown area.

3. Government should recover sidewalks and road setbacks which have been totally invaded by commercial activities in Aba, and develop paid curb-parking by the sidewalks downtown, as alternative to on-street parking. Curb parking when properly priced would also balance both extremes of free on-street parking which encourages traffic congestion downtown, and on-street parking prohibition which negatively impacts downtown shopping. Besides, paid curb parking can be a great source of internal revenue for municipalities.
4. In parts of the city where off-street parking is not available or feasible, on-street parking must be a design consideration to ensure user convenience and economic well being of abutting properties. Addition of on-street parking is often coupled with other roadway changes such as carriage way expansion, conversion to two-way operation, widening of road shoulder widths and sidewalks, improved streetscape etc. With proper planning certain high density inner city areas of Aba with lesser traffic capacity may be developed to sustain guided on-street parking. Experience from other cities has demonstrated that a comprehensive and well-managed parking program results in significant reductions in parking violations, substantial increases in on-street parking space availability, and major increases in parking related revenues.

5. A situation where people find it extremely inconveniencing to travel to the city centre with their cars may be to the detriment of downtown activities especially shopping and service industries. Moreover the predominance of KEKE as mode of travel to the city may be counter productive to efforts at reducing traffic congestion. Therefore government should relax the stringent penalties attached to violation of on-street parking regulations. Rather than be totally prohibitive, the traffic regulations should prescribe conditions upon which motorists may be allowed to park on-street, provided such conditions would advance the goal of mitigating traffic congestion and road crash. For instance, on-street parking may be permissible within road sections at least 180meters from an intersection. Some cities have carefully marked road sections where on-street parking may be permitted along a given road lane. This method is hereby recommended to ensure guided on-street parking in the city of Aba.

\section{ACKNOWLEDGEMENTS}

The author hereby acknowledges Dr. Obinna Ubani of the Department of Urban and Regional Planning, University of Nigeria Enugu, for his supervisory role and brotherly assistance in the course of this study. Thank you Dr. O. J. May I also thank all my research assistants during this study - mainly the final year students of Urban and Regional Planning (2016) of Abia State Polytechnic Aba. God bless you all.

\section{REFERENCES}

[1] A. Aderamo and T. Atomode. Traffic Congestion at Road Intersections in Ilorin, Nigeria. Australian Journal 
of Basic and Applied Sciences. 2011, Vol.5(9):

Pp.1439-1448.

www.ajbasweb.com/old/ajbas/2011/September2011/1439-1448.pdf

[2] Y. Ahmed. Menace of Illegal Motor Parks in Nigerian Urban Environment: Example from Ilorin City. Journal of Geography and Regional Planning. 2014, Vol.8(2),Pp.37-46. http://www.academicjournals.org/JGRP

[3] J. K. Andrew, and J. C. Peter. Influence of parking tariffs on parking occupancy levels by trip purpose. Transport Policy. 2006, Vol.13. pp.487-495. https://doi.org/10.1016/j.tranpol.2006.05.006

[4] R. Asiyanbola and A. Akinpelu. The challenges of onstreet parking in Nigerian Cities' Transportation Routes. International Journal of Development and Sustainability. 2012, Vol.1 (2). Pp. 476-489. www.isdsnet.com/ijds

[5] A. Charles, O. Richter, and M. Abdul. Parking Management in Metropolitan Cities in West Africa Case Study of the Kumasi Paid Parking Scheme, Ghana. International Refereed Journal of Engineering and Science. 2014, Vol. 3(6). Pp.01-08. www.irjes.com/Papers/vol3issue6/Vesion\%202/A360108.pdf

[6] R. Ellis. On-Street Management Programs, Proceedings of ITE's 1987 National Conference on Strategies to Alleviate Traffic Congestion. 1987, 1, pp. 498-504.

[7] J. Kennedy. A Systems Approach to On-Street Parking Enforcement. Parking, February 1994 Issue, pp.31-34. http://worldcat.org/oclc/3041176

[8] T. Kok. Draft Parking Policy for the City of Cape Town October, 2013.

[9] M. Meyer, A. ASCE, M. McShane. Parking Policy and Downtown Economic Development. Journal of Urban Planning and Development. 1983, Vol. 109(1) pp. 27-
43. 9488(1983)109:1(27)

https://doi.org/10.1061/(ASCE)0733-

[10] T. Martin. Chicago Banks on Private Parking. Wall Street Journal (online). 2008, http://online.wsj.com/article/SB1228263

[11]F. Mohamed. Sustainable Transport Project for Egypt. Egyptian Environmental Affaires Agency, 2012.

[12] S. O. Olorunfemi, A. Olowosegun, A. E. Koffi, E. E. Okoko, and S. Mobolaji. Examination of On-Street Parking and Traffic Congestion Problems in Lokoja. Civil and Environmental Research. 2014, Vol. 6(4) pp. 95-104. www.iiste.org

[13] S. Osoba. Appraisal of parking problems and traffic management measures in Central business district in Lagos, Nigeria. Journal of sustainable development. 2012, Vol.5(8). Pp. 105-115. http://dx.doi.org/10.5539/jsd.v5n8p105

[14] J. Obot, E. Etim, and J. Atser. Intra -Urban traffic and parking demand in Uyo Urban area. Global Journal of social sciences. 2009, Vol. 8 (2). Pp.61-68. www.proquest.com/openview/

[15]T. Rye. "Using Planning to Manage Parking - UK Experiences", Paper to Seminar on Parking Management and Land Use Regulations, Radisson SAS Plaza Hotel, Oslo. 2005. http://Rye\%2BOslo\%2Bparking\%2B200905\%2Bp1

[16] T. Rye. Parking Management, a Contribution Towards Liveable Cities. German Technical Cooperation (GTZ), Module 2c, Sustainable Transport, A source book for policy makers in developing countries. 2011.

[17]D. Shoup. The High Cost of Free Parking. Planners Press, Chicago. 2005. www.amazonaws.com

[18] Washington State Department of Transportation (WashDOT). "Local Government Parking Policy and Commute Trip Reduction, 1999 Review,"p.4. http://www.wsdot.wa.gov/tdm/tripreduction/download/ 1999_parking_policy_review.pd

\section{Appendix - A1: One Way ANOVA}

\begin{tabular}{|c|c|c|c|c|c|}
\hline & $\begin{array}{l}\text { Sum of } \\
\text { Squares }\end{array}$ & $\mathrm{df}$ & Mean Square & $\mathrm{F}$ & Sig. \\
\hline Between Groups & 1918507 & 1 & 1918506.667 & 18.819 & .000 \\
\hline Within Groups & 3058371 & 30 & 101945.711 & & \\
\hline Total & 4976878 & 31 & & & \\
\hline
\end{tabular}

Source: SPSS output

$$
\text { Appendix - A2: }
$$


permitted

\begin{tabular}{|c|c|c|c|c|}
\hline Part of the city & Road names & $\begin{array}{l}\text { On-street parking } \\
\text { capacity }\end{array}$ & $\begin{array}{l}\text { Carriage way } \\
\text { Width }(m)\end{array}$ & $\begin{array}{l}\text { Shoulder } \\
\text { Width (m) }\end{array}$ \\
\hline \multirow{19}{*}{$\begin{array}{l}\text { Roads in } \\
\text { the CBD }\end{array}$} & Park road & 65 & 10.5 & $0.8 \mathrm{~m}$ \\
\hline & Pound road & 40 & 8.5 & 0.6 \\
\hline & St. Michaels' road & 70 & 10 & 1.0 \\
\hline & Ehi road & 38 & 9 & 0.6 \\
\hline & Tenant road & 30 & 7.5 & 0.5 \\
\hline & Clifford road & 32 & 7.5 & 0.7 \\
\hline & Hospital road & 43 & 8 & 0.6 \\
\hline & Market road & 31 & 7.7 & 0.4 \\
\hline & Georges road & 15 & 8 & 0.2 \\
\hline & Ngwa road & 89 & 12 & 1.4 \\
\hline & School road & 68 & 10 & 1.0 \\
\hline & River layout road & 33 & 11.5 & 0.8 \\
\hline & East road & 21 & 9 & 0.4 \\
\hline & Constitution crest & 0.0 & 7.5 & 0.0 \\
\hline & Asa road & 340 & 24 & 1.5 \\
\hline & Jubilee road & 37 & 8.5 & 0.6 \\
\hline & Cemetery road & 0.0 & 7.5 & 0.0 \\
\hline & Eziukwu road & 102 & 12 & 1.2 \\
\hline & Milverton Road & 98 & 14 & 1.2 \\
\hline \multirow{13}{*}{$\begin{array}{l}\text { Roads Outlying } \\
\text { Areas }\end{array}$} & Port-Harcourt road & 1364 & 24 & 2.1 \\
\hline & Aba-Owerri road & 1134 & 26 & 2.5 \\
\hline & Okigwe road & 219 & 14 & 1.5 \\
\hline & Ikot-Ekpene road & 1032 & 24 & 2.0 \\
\hline & Umoba road & 41 & 12 & 0.4 \\
\hline & Obohia road & 98 & 9.5 & 1.2 \\
\hline & Ohanku & 174 & 10.5 & 1.4 \\
\hline & Ukaegbu & 69 & 10.5 & 0.8 \\
\hline & Omuma road & 604 & 12 & 1.2 \\
\hline & Izuogu road & 591 & 10 & 1.5 \\
\hline & Ndiegoro road & 812 & 12 & 1.5 \\
\hline & Umuokpu road & 1013 & 12 & 1.8 \\
\hline & Urrata road & 849 & 11.5 & 1.5 \\
\hline
\end{tabular}

Source: Researcher's Survey, 2016

\section{Appendix - B 1:}

SPSS output for Choice of Mode

\begin{tabular}{|l|l|l|l|}
\hline what is your choice of mode during evening hours & Value & Df & $\begin{array}{l}\text { Asymp. } \\
\text { sided })\end{array}$ \\
\hline Private car Pearson Chi-Square & $133.225^{\mathrm{a}}$ & 9 & .000 \\
Likelihood Ratio & 99.916 & 9 & .000 \\
Linear-by-Linear Association & 90.433 & 1 & .000 \\
N of Valid Cases & 113 & & \\
\hline
\end{tabular}




\begin{tabular}{|ll|l|l|l|}
\hline Mini bus & Pearson Chi-Square & $40.518^{\mathrm{b}}$ & 6 & .000 \\
& Likelihood Ratio & 47.752 & 6 & .000 \\
& Linear-by-Linear Association & 53.193 & 1 & .000 \\
& N of Valid Cases & $7.000^{\mathrm{c}}$ & 6 & .321 \\
\hline Taxi & 8.376 & 6 & .212 \\
& Pearson Chi-Square & 4.044 & 1 & .044 \\
& Likelihood Ratio & 7 & & \\
& Linear-by-Linear Association & $88.399^{\mathrm{d}}$ & 6 & .000 \\
& N of Valid Cases & 31.548 & 6 & .000 \\
\hline KEKE & Pearson Chi-Square & 42.250 & 1 & .000 \\
& Likelihood Ratio & 187 & & \\
\hline
\end{tabular}

a. 13 cells $(81.3 \%)$ have expected count less than 5 . The minimum expected count is .05 .

b. 6 cells $(50.0 \%)$ have expected count less than 5 . The minimum expected count is .30 .

c. 12 cells $(100.0 \%)$ have expected count less than 5 . The minimum expected count is .14.

d. 10 cells $(83.3 \%)$ have expected count less than 5 . The minimum expected count is .02 .

\section{Appendix - B 2:}

The SPSS $\mathrm{X}^{2}$ output data for volume of trips

\begin{tabular}{|ll|l|l|l|}
\hline Volume of trip during morning hours & Value & df & Asymp. Sig. (2-sided) \\
\hline $1-2$ & Pearson Chi-Square & $54.519^{\mathrm{a}}$ & 2 & .000 \\
& Likelihood Ratio & 24.045 & 2 & .000 \\
& Linear-by-Linear & 19.722 & 1 & .000 \\
& Association & & & \\
& N of Valid Cases & 224 & & \\
\hline $3-4$ & Pearson Chi-Square & $66.739^{\mathrm{b}}$ & 3 & .000 \\
& Likelihood Ratio & 59.354 & 3 & .000 \\
& Linear-by-Linear & 49.929 & 1 & .000 \\
& Association & & & \\
& N of Valid Cases & 131 & & \\
\hline $5-6$ & Pearson Chi-Square &. & & \\
& N of Valid Cases & 1 & & \\
\hline above 6 & Pearson Chi-Square &. & & \\
& N of Valid Cases & 2 & & \\
\hline
\end{tabular}

a. 2 cells $(33.3 \%)$ have expected count less than 5. The minimum expected count is .29.

b. 4 cells $(50.0 \%)$ have expected count less than 5 . The minimum expected count is 1.03 . 
Appendix - B 3:

The SPSS $X^{2}$ output data for choice of travel destination

\begin{tabular}{|ll|l|l|l|l|l|}
\hline $\begin{array}{l}\text { Which part of the city do you more frequently } \\
\text { visit day time }\end{array}$ & Value & $\mathrm{df}$ & $\begin{array}{l}\text { Asymp. Sig. } \\
\text { (2-sided) }\end{array}$ & $\begin{array}{l}\text { Exact Sig. (2- } \\
\text { sided) }\end{array}$ & $\begin{array}{l}\text { Exact Sig. } \\
\text { (1-sided) }\end{array}$ \\
\hline CBD & Pearson Chi-Square & $61.533^{\mathrm{a}}$ & 1 & .000 & & \\
& Continuity Correction ${ }^{\mathrm{b}}$ & 57.662 & 1 & .000 & & \\
& Likelihood Ratio & 53.187 & 1 & .000 & .000 \\
& Fisher's Exact Test & & & & \\
& Linear-by-Linear Association & 61.111 & 1 & .000 & & \\
& N of Valid Cases & 146 & & & & \\
\hline Out lying area & Pearson Chi-Square & $88.621^{\mathrm{c}}$ & 1 & .000 & & \\
& Continuity Correction & & & \\
& Likelihood Ratio & 86.011 & 1 & .000 & & \\
& Fisher's Exact Test & 94.886 & 1 & .000 & & \\
& Linear-by-Linear Association & 88.211 & 1 & .000 & & \\
& N of Valid Cases & 216 & & & & \\
\hline
\end{tabular}

a. 0 cells $(.0 \%)$ have expected count less than 5 . The minimum expected count is 6.36 .

b. Computed only for a $2 \times 2$ table

c. 0 cells $(.0 \%)$ have expected count less than 5 . The minimum expected count is 38.30 .

Appendix - B 4:

The $\mathrm{X}^{2}$ output data for choice of Mode between CBD and Outskirts

\begin{tabular}{|l|l|l|l|}
\hline & Value & df & Asymp. Sig. (2-sided) \\
\hline Pearson Chi-Square & $317.425^{\mathrm{a}}$ & 9 & .000 \\
Likelihood Ratio & 195.539 & 9 & .000 \\
Linear-by-Linear Association & 89.424 & 1 & .000 \\
N of Valid Cases & 363 & & \\
\hline
\end{tabular}

a. 8 cells $(50.0 \%)$ have expected count less than 5 . The minimum expected count is .03 .

Appendix - B 5:

Output data for Frequency of trips between CBD and Outlying areas

\begin{tabular}{|l|l|l|l|}
\hline & Value & Df & Asymp. Sig. (2-sided) \\
\hline Pearson Chi-Square & $220.975^{\mathrm{a}}$ & 9 & .000 \\
Likelihood Ratio & 218.573 & 9 & .000 \\
Linear-by-Linear Association & 143.138 & 1 & .000 \\
N of Valid Cases & 360 & & \\
\hline
\end{tabular}

a. 6 cells $(37.5 \%)$ have expected count less than 5 . The minimum expected count is .13 . 